\title{
Do private equity owners increase risk of financial distress and bankruptcy? ${ }^{\text {i⿱ }}$
}

\author{
Tereza Tykvová*, Mariela Borell \\ Centre for European Economic Research (ZEW), Mannheim, Germany
}

\section{A R T I C L E I N F O}

Available online 9 November 2011

\section{JEL classification:}

G20

G24

G34

Keywords:

Private equity

Buyout

Financial distress

Bankruptcy

\begin{abstract}
A B S T R A C T
In this study, we investigate financial distress risks of European companies around the buyout event in the period between 2000 and 2008. In addition, we analyze whether buyout companies go bankrupt more often than comparable non-buyout companies. Our results suggest that private equity investors select companies which are less financially distressed than comparable non-buyout companies and that the distress risk increases after the buyout. Despite this increase, private equity-backed companies do not suffer from higher bankruptcy rates than comparable non-buyout companies. In fact, when companies are backed by experienced private equity funds, their bankruptcy rates are even lower. These findings indicate that experienced investors are better able to manage distress risks than their inexperienced counterparts.
\end{abstract}

(C) 2011 Elsevier B.V. All rights reserved.

Some financial investors do not waste any thoughts on the people whose jobs they destroy. They remain anonymous, do not have a face, pounce upon companies like swarms of locusts, graze on them and continue on their way. We are fighting against this form of capitalism.

Franz Muentefering, former chairman of the Social Democratic Party (SPD) in Germany (in an interview, Bild am Sonntag, 17 April 2005)

\section{Introduction}

There is some controversy regarding the key sources of success in the private equity (PE) model. Does this success come from value creation or from value transfer? Most scholars agree that PE investors create value by increasing productivity and profitability of their portfolio companies (e.g., Davis et al., 2008; Harris et al., 2005; Kaplan, 1989; Lichtenberg and Siegel, 1990, or Smith, 1990). Starting with Jensen (1986 and 1989) many researchers argue that these improvements result from a superior governance model that PE investors implement in their portfolio companies. An essential part of this superior governance model is a disciplining role of debt. Debt prevents managers from wasting resources, i.e., from excessively investing free cash-flows in projects with negative net present values, because the managers are forced to repay the loans.

Some scholars point out potential negative effects of debt level increases in buyout companies and argue that PE investors rather transfer value from other stakeholders than create it. Higher debt levels boost tax shields, which raise PE returns (Guo

\footnotetext{
We gratefully acknowledge financial support from Deutsche Forschungsgemeinschaft (DFG, grant number TY 83/1-1) and from the 7th Research Framework Programme (FP7) of the European Commission (grant agreement number 217485). The current version has benefited from comments by an anonymous referee and the special issue editors, Don Siegel, Hany Shawky, and Mike Wright, as well as Nick Wilson, Fabio Bertoni, Na Dai, Sophie Manigart, José Martí, Matthias Meitner, and the participants in the JCF Special Issue Workshop in New York, in the FMA European Conference in Porto, in the EFM Symposium on Alternative Investments in Toronto, and in the SEEK Conference in Mannheim. We thank Manuel Wiegand for excellent research assistance.

* Corresponding author at: Centre for European Economic Research (ZEW), Dept. International Finance and Financial Management, P.O. Box 103443, D-68034 Mannheim, Germany. Tel.: +49621 1235 147; fax: + 496211235223.

E-mail address: tykvova@zew.de (T. Tykvová).
} 
et al., 2011) and represent a transfer from taxpayers. Moreover, anecdotal evidence suggests that it is not uncommon for PE investors to increase debt levels in order to pay out special dividends for themselves (dividend recaps), which may be viewed as a transfer from other shareholders. ${ }^{1}$ In addition, increases in debt levels could induce a higher risk of financial distress and bankruptcy (e.g., Kaplan and Stein, 1993), harming other shareholders and debtholders. Finally, PE investors may transfer value from the "financial system", as increases in bankruptcy rates may negatively affect financial institutions providing transaction financing. Policy debates are often led by concerns about harmful effects of excessive debt levels, increased financial distress risks and bankruptcy rates in companies which undergo buyout transactions and by concerns about potential broader negative implications on financial institutions and the stability of the financial system when large buyout credits fail.

We contribute to this discussion by investigating financial distress risk and bankruptcy rates of European companies around their buyouts in the period 2000-2008. Thus, we add to a growing literature documenting the real effects of PE financing. We shed some light on the potential negative effects of PE financing, whereas the existing literature predominantly focuses on the positive side of PE financing, such as links between PE investment and operating performance (e.g., Davis et al., 2009; Guo et al., 2011; Kaplan, 1989), PE investment and employment (e.g., Cressy et al., 2007; Davis et al., 2008, 2009; Lichtenberg and Siegel, 1990) or PE investment and innovation (e.g., Lerner et al., 2011; Popov and Roosenboom, 2009). Our research is also related to the recent literature that investigates how debt market conditions affect the capital structure in PE transactions. Axelson et al. (2010) find that when debt market conditions are favorable, PE investors increase debt levels. We add to this strand of research by analyzing whether companies subject to buyouts in favorable debt market conditions face a higher risk of bankruptcy than comparable non-buyout companies or than companies that are subject to buyouts in less favorable market conditions.

Our paper is also related to a vast literature addressing the issue of how syndication behavior and investors' experience affect portfolio companies. It is a priori not clear how syndication and experience are related to financial distress risks and bankruptcy rates. Our research contributes to filling this research gap. As to syndication, syndicates are ready to invest in more risky companies and strategies than stand-alone investors (Filatotchev et al., 2006) on the one hand. This may result in higher bankruptcy rates of companies backed by syndicates. On the other hand, syndicates are endowed with more resources than stand-alone investors. They can use these resources to prevent their portfolio companies from experiencing financial difficulties. If the latter effect prevails, we will observe lower bankruptcy rates in companies backed by syndicates.

As to experience, there are at least three arguments for why we expect experienced PE investors to be associated with lower financial distress risks and bankruptcy rates. First, an inexperienced investor may want to "show up" by investing in more risky companies and strategies, which possess a higher upside potential, but which more often end in financial distress and bankruptcy. Second, experienced investors have better know-how and instruments to avoid bankruptcy than inexperienced investors. One of the essential reasons is that they have easier access to loans (e.g., Demiroglu and James, 2010; Ivashina and Kovner, 2011). Third, experienced investors want to maintain their reputational stake vis a vis their capital providers and vis a vis financial institutions, which provide debt financing. Therefore, they have more incentives to avoid bankruptcy than inexperienced investors with a lower reputational stake. But there is also at least one argument in the opposite direction. Experienced investors may be better able to transfer value, for example through dividend recaps, because, compared to inexperienced investors, they have greater bargaining power, better negotiation skills and superior information, which may increase the risk of financial distress and bankruptcy in their portfolio companies.

Another contribution of our paper is that we provide a more comprehensive picture of the real effects of PE financing than many other existing studies, which often analyze investors or companies from a single country or which focus on listed companies only. In contrast to most of the aforementioned studies, our study includes several countries and we collect data on privately held companies. In addition, our sample including information on a large number of buyout as well as non-buyout companies and the pre- and post-buyout characteristics of the former group makes the identification of a causal effect more compelling than in most previous studies. To take into account that PE targets are not randomly chosen, we employ a matching procedure, a panel approach with firm fixed effects, and, finally, an instrumental variable approach.

We start with a sample covering more than 8 million companies from 15 countries. From this sample, we consider all buyout transactions and select comparable control firms. We focus on European transactions within the time horizon 2000-2008 because since the beginning of the new millennium, PE transactions have spread more and more throughout Europe. According to Kaplan and Strömberg (2009), 49\% of the target enterprise value in buyout transactions were concentrated in Europe, compared to $44 \%$ in the US and Canada during the period 2000-2004. A more technical reason for our focus on European companies is that we need accounting data for these companies in order to measure their financial distress risk. Unfortunately, most PE transactions involve privately held companies, which are not required to disclose financial information in the US. In contrast, European companies have relatively stringent disclosure requirements.

Our results suggest that PE investors select firms which have a lower financial distress risk than comparable non-buyout companies and that the financial distress risk increases after the buyout transaction. However, the financial distress risk in buyout companies does not exceed the distress risk in comparable non-buyout companies three years after the buyout. In addition, our findings indicate that buyout companies do not suffer from bankruptcy more often than comparable non-buyout companies. This

\footnotetext{
1 The Wall Street Journal reports that between 2003 and mid-2006, US PE-backed companies raised USD 69 billion additional debt "primarily to pay dividends to private equity owners" (Greg Ip \& Henny Sender, Private money: the new financial order, Wall Street Journal, 25 July 2006 , p. A1). An example of such a transaction is the case of Debenhams. This company was taken private in 2003 by a syndicate of CVC, Texas Pacific Group, and Merrill Lynch Private Equity with a package comprising approximately $£ 1.4$ billion of debt and $£ 600 \mathrm{~m}$ of equity. It was twice refinanced with debt. As a consequence, debt increased to $£ 1.9$ billion. These refinancings allowed $£ 1.2$ billion (twice the original equity stake) to be "taken out of Debenhams" and returned to the PE syndicate as a "special dividend" (Jonathan Braude, Debenhams to make debut, TheDeal.com, 21 April 2006).
} 
seems to be true even for buyouts taking place under favorable debt market conditions. Our results further lend support to the hypothesis that PE investors even decrease a company's bankruptcy probability when they are experienced.

The remainder of the paper is structured as follows. The next section summarizes the background and related literature. In Section 3 we describe financial distress risk measures. Section 4 gives an overview of the data. Section 5 analyzes the relationship between PE financing and financial distress. In Section 6, we investigate the relationship between PE financing and bankruptcy rates. Section 7 concludes.

\section{Theoretical background: financial distress and bankruptcy}

\subsection{Impact of PE investors}

PE transactions are typically characterized by an increase in debt levels (e.g., Kaplan, 1989). The obligation to service this debt can be viewed as a positive or a negative outcome.

On the positive side, large debt levels discipline managers who might otherwise have incentives to invest in projects with a negative net present value (e.g., Jensen, 1986). PE investors may limit the waste of free cash-flow and in this way increase the portfolio companies' efficiency and productivity.

On the negative side, high debt levels may increase the risk of financial distress and bankruptcy. Kaplan and Stein (1993), who analyze large US buyouts completed in the late 1980s, suggest that high debt levels may have increased bankruptcy likelihoods. Extensive literature documents that market and business cycles and, in particular, the relative price of debt vs. equity affect the level of PE activity and the use of debt (e.g., Axelson et al., 2010; Guo et al., 2011; Phalippou and Zollo, 2005). When debt becomes cheaper relative to equity, PE investors are able to increase their returns by raising debt levels (e.g., Kaplan and Strömberg, 2009). Thus, we may observe higher bankruptcy risks after the buyout and also compared to non-buyout companies, in particular when debt market conditions are favorable.

\subsection{Impact of PE syndication}

There are several reasons to believe that syndicates choose companies with different financial characteristics than stand-alone investors and that the development of these companies after the buyout event differs.

One might expect syndicates to be willing to invest in more risky companies than stand-alone investors (e.g., Filatotchev et al., 2006) because they will be better able to manage these risks for at least three reasons. First, when investors have access to different sources of information, syndication delivers a second opinion on the future prospects of the company (e.g., Casamatta and Haritchabalet, 2007; Lerner, 1994), which leads to a better selection and may limit the risk that a particular company ends in bankruptcy. Second, when investors combine their complementary skills, syndication may result in more intense monitoring and higher-quality support during the investment phase (e.g., Brander et al., 2002; Cumming and Walz, 2010; Tian, 2011), which further reduces the likelihood of bankruptcy. Third, a syndicate of PE investors has a larger potential pool of financial resources than a stand-alone investor to help a portfolio company when it experiences financial difficulties.

These benefits only show to advantage if they outweigh syndication cost. Syndication is a complex process which usually gives rise to agency problems emerging from information asymmetries within the syndicate (Wright and Lockett, 2003). In some situations, one investor possesses more information about the quality of the deal. If this is the case, this investor may be inclined to take a less informed partner on board only for low-quality deals, which in turn leads to adverse selection. In other settings, syndication may result in moral hazard and free riding problems since the investors do not mutually observe their efforts in portfolio companies' monitoring and support. All these problems are potentially aggravated when companies are in financial distress. Despite the existence of "drag along" and other covenants, coordination between PE investors might thus be difficult when a restructuring of financially distressed buyouts is required (e.g., Citron and Wright, 2008). Therefore, syndicates might prefer to invest in less distressed companies and may also be less able to avoid financial distress and bankruptcy.

\subsection{Impact of PE experience}

We conjecture that PE experience shapes the choice of buyout targets with certain financial characteristics as well as their post-buyout development.

One might expect that inexperienced investors tend to invest in more risky companies in order to "show up". These companies fail more often, but, with a low probability, they may turn into an impressive success story. Inexperienced PE investors may want to bet on this success to become visible for their capital providers and for financial institutions providing debt financing. But even if they invested in similar companies as experienced investors, there would be several reasons for us to expect a higher risk of financial distress and bankruptcy with inexperienced investors. It may be easier for experienced PE investors to react when a company gets into financial difficulties because they obtain loans on more favorable conditions than their inexperienced counterparts (e.g., Demiroglu and James, 2010; Ivashina and Kovner, 2011). In addition, experienced investors have a higher stake of reputational capital to protect, which makes them more eager to avoid bankruptcies within their portfolio companies than inexperienced investors. Finally, experienced PE investors have superior selection and value-adding abilities, which lead to higher success rates. Sorensen (2007) suggests that more experienced investors make more successful investments in terms of investing in better companies which are more likely to go public. Nahata (2008) shows that companies backed by more experienced and reputable venture capitalists are more likely to exit successfully (via trade sale or IPO). Inexperienced investors realize a higher fraction of unsuccessful exits, i.e. liquidations. 
Alternatively, the risk of distress and bankruptcy may be higher with experienced than with inexperienced investors because experienced investors have a higher bargaining power, better negotiation skills and superior information. In addition, they are able to obtain more debt financing from financial institutions than their inexperienced counterparts, which they may use to increase debt levels and, thus, risks in their portfolio companies. All in all, experienced PE investors may be better able to transfer value from other stakeholders.

\section{Financial distress risk measures}

The literature uses two approaches to measure companies' financial distress. The first approach is based on accounting data. In general, ratios measuring profitability, liquidity, and solvency prevail as the most significant indicators. The second approach relies on stock market data (or their combination with accounting data). For our sample of mostly private firms we rely on the first approach. We employ indices which have been designed for or can easily be adapted to private firms. These are: Zmijewski-score (Zmijewski, 1984), O-score (Griffin and Lemmon, 2002; Ohlson, 1980), and Z-score (Altman, 1968) and its extension for private firms (Altman, 2002).

Zmijewski-score equals:

$$
Z M=-4.336-4.513 \cdot \frac{N I}{T A}+5.679 \cdot \frac{T L}{T A}+0.004 \cdot \frac{C A}{C L},
$$

with NI being net income (profit/loss for period); TA being total assets; TL total liabilities; CA current assets; and CL current liabilities. A higher Zmijewski-score value indicates a higher financial distress risk.

We follow the implementation of Ohlson (1980) by Griffin and Lemmon (2002) and compute the O-score as:

$$
\begin{aligned}
O= & -1.32-0.407 \cdot \log T A+6.03 \cdot \frac{T L}{T A}-1.43 \cdot \frac{W C}{T A}+0.076 \cdot \frac{C L}{C A}-1.72 \cdot T L d u m m y-2.37 \cdot \frac{N I}{T A}-1.83 \cdot \frac{F F O}{T L} \\
& +0.285 \cdot N L d u m m y-0.521 \cdot \frac{N I_{t}-N I_{t-1}}{\left|N I_{t}\right|+\left|N I_{t-1}\right|},
\end{aligned}
$$

with TA being inflation-adjusted total assets; $T L$ total liabilities; WC working capital; $C L$ current liabilities; $C A$ current assets; TLdummy being 1 if total liabilities are higher than total assets, zero otherwise; NI being net income (profit/loss for period); FFO being funds from operations; and NLdummy being 1 if the company realized a net loss in the last two years, zero otherwise. A higher O-score value is associated with a higher financial distress risk.

Finally, the Z-score is defined as:

$$
Z=0.717 \cdot \frac{W C}{T A}+0.847 \cdot \frac{r e t E A R N I N G S}{T A}+3.107 \cdot \frac{E B I T}{T A}+0.420 \cdot \frac{M V}{T L}+0.998 \cdot \frac{S A L}{T A},
$$

with WC being working capital; TA total assets; retEARNINGS retained earnings; EBIT earnings before interest and taxes; MV market value of equity; $T L$ total liabilities; and SAL sales. The five subratios which form this score reflect (i) liquid assets in relation to company size, (ii) profitability, (iii) operating efficiency apart from tax and leveraging factors, (iv) market dimension, (v) sales turnover. We lack data to calculate two of these subratios and employ other shareholder funds instead of retained earnings in (ii) and book value instead of market value in (iv). The higher the value of the Z-score, the less financially distressed the company. ${ }^{2}$

\section{Data}

Our sample consists of buyout and non-buyout companies from the EU-15 countries. We obtain accounting data on companies operating in these countries from Amadeus database, which contains detailed information from balance sheets and profit/loss accounts for more than 18 million European companies. We exclude companies for which we do not find accounting information. We obtain the information of whether a company has been subject to a buyout from Zephyr database, which contains information on over 600,000 mergers and acquisitions, private equity and venture capital transactions, and initial public offerings. ${ }^{3}$ We exclude non-buyout companies from those country-industry ${ }^{4}$-year groups in which we do not observe any buyouts. We consider buyout companies only until the year of PE investor's exit. We provide a list of variables we use in this paper with their descriptions and sources in Appendix 1.

\subsection{Buyouts}

From Zephyr database, we extract all completed transactions from the period between 2000 and 2008 in the EU- 15 countries classified as "institutional buyout". We add all acquisitions with transaction financing described as "private equity" or "leveraged buyout", which were undertaken either by a financial sponsor or by an acquirer whose business description includes the term "private equity". We exclude

\footnotetext{
${ }^{2}$ Altman defines the following zones of discrimination: $Z>2.9$ - safe zone, $1.23<Z<2.9$ - gray zone, $Z<1.23$ - distress zone.

3 Scholars working in the field of private equity and venture capital have become aware of the existence of this database in recent years (e.g., Abdesselam et al., 2008; Goossens et al., 2008, Bloom et al., 2010, Brav et al., 2009; Beuselinck et al., 2009; Prijcker et al., 2009; Schertler and Tykvová, 2011).

${ }^{4}$ Industries are 2-digit NACE Rev. 2 codes.
} 
minority deals. We also remove secondary buyouts since these transactions may involve different types of companies and may have different consequences for financial distress risk and bankruptcy probability than primary buyouts. We end up with 1842 buyouts.

Table 1 reports the composition of the buyout sample by year, country and industry. It shows that the majority of buyouts take place in 2007 after a continuous increase since 2002. In 2008 the deal frequency dropped as a consequence of the financial crisis. The largest buyout markets are the United Kingdom and France. Most transactions take place in the manufacturing industry.

We split the buyouts into subsamples of syndicated and stand-alone transactions as well as subsamples of transactions by experienced and inexperienced PE investors. Almost $19 \%$ of the transactions are syndicated and about $50 \%$ of the buyouts are carried out by experienced PE investors.

We classify a buyout as a syndicated transaction if the number of acquirers is disclosed and is larger than one. We classify it as a stand-alone transaction if the number of acquirers is disclosed and equals one. Those buyouts for which we do not have information on the number of investors ( since the names of the acquirers are missing completely or are not explicitly disclosed, e.g., when a management buyout team or private individuals buy the company) cannot be assigned to either of the subsamples. Therefore, the sum of both subsamples' counts is lower than the total number of buyouts.

We build the subsamples of buyouts by experienced and inexperienced PE investors by considering the average experience of all $\mathrm{PE}$ investors involved in a particular deal. The experience of each PE investor in a particular transaction is proxied by the number of all (worldwide) transactions this PE investor carried out prior to the transaction concerned. If the "name" of the investor is management buyout team, private individuals, or similar (i.e., there is information in this field, but the name is not explicitly disclosed), we set the experience equal to zero. Our subsample of buyouts by experienced PE investors includes those buyouts in which the average

Table 1

Number of buyouts by year, country and industry.

\begin{tabular}{|c|c|c|c|c|c|}
\hline Year & $\begin{array}{l}\text { Full } \\
\text { sample }\end{array}$ & $\begin{array}{l}\text { Syndicated } \\
\text { transactions }\end{array}$ & $\begin{array}{l}\text { Stand-alone } \\
\text { transactions }\end{array}$ & $\begin{array}{l}\text { Experienced } \\
\text { PE investors }\end{array}$ & $\begin{array}{l}\text { Inexperienced } \\
\text { PE investors }\end{array}$ \\
\hline 2000 & 44 & 2 & 13 & 5 & 11 \\
\hline 2001 & 69 & 1 & 9 & 3 & 8 \\
\hline 2002 & 53 & 2 & 22 & 13 & 20 \\
\hline 2003 & 88 & 10 & 56 & 37 & 36 \\
\hline 2004 & 139 & 12 & 96 & 62 & 66 \\
\hline 2005 & 264 & 38 & 157 & 121 & 124 \\
\hline 2006 & 349 & 81 & 218 & 188 & 141 \\
\hline 2007 & 457 & 71 & 320 & 219 & 213 \\
\hline 2008 & 379 & 47 & 260 & 164 & 185 \\
\hline Total & 1842 & 264 & 1151 & 812 & 804 \\
\hline
\end{tabular}

Country

Austria

Belgium

Denmark

Finland

France

Germany

Greece

Ireland

Italy

Luxembourg

Netherlands

Portugal

Spain

Sweden

United Kingdom

Total

$\begin{array}{rr}18 & \\ 85 & 1 \\ 55 & \\ 49 & \\ 441 & \\ 207 & 67 \\ 4 & 32 \\ 9 & \\ 124 & \\ 2 & \\ 121 & 25 \\ 22 & \\ 165 & 1 \\ 126 & 4 \\ 414 & 11 \\ 1842 & 45\end{array}$

$\begin{array}{rr}3 & 13 \\ 13 & 47 \\ 2 & 51 \\ 7 & 40 \\ 67 & 252 \\ 32 & 152 \\ 1 & 3 \\ 0 & 5 \\ 25 & 75 \\ 1 & 1 \\ 15 & 74 \\ 2 & 14 \\ 40 & 93 \\ 11 & 97 \\ 45 & 234 \\ 264 & 1151\end{array}$

$\begin{array}{rr}11 & 7 \\ 36 & 37 \\ 30 & 24 \\ 32 & 15 \\ 185 & 198 \\ 109 & 88 \\ 3 & 1 \\ 0 & 7 \\ 56 & 53 \\ 2 & 0 \\ 50 & 57 \\ 8 & 10 \\ 84 & 64 \\ 68 & 43 \\ 138 & 200 \\ 812 & 804\end{array}$

Industry

Manufacturing, mining and quarrying

Trade, transportation and storage

Administration and support services

Information and communication

Financial and insurance activities

Public administration, education

Construction

Other services

Real estate activities

Agriculture, forestry and fishing

Total

\begin{tabular}{|c|c|c|c|c|}
\hline 618 & 90 & 388 & 280 & 276 \\
\hline 397 & 55 & 245 & 175 & 178 \\
\hline 330 & 49 & 202 & 147 & 139 \\
\hline 153 & 25 & 100 & 67 & 68 \\
\hline 146 & 12 & 104 & 63 & 60 \\
\hline 61 & 10 & 32 & 23 & 24 \\
\hline 57 & 9 & 29 & 22 & 22 \\
\hline 51 & 11 & 29 & 22 & 23 \\
\hline 26 & 3 & 20 & 12 & 13 \\
\hline 3 & 0 & 2 & 1 & 1 \\
\hline 1842 & 264 & 1151 & 812 & 804 \\
\hline
\end{tabular}


experience of the participating investors exceeds one. If it is one or below, it belongs to the subgroup of buyouts by inexperienced PE investors. If the name is missing completely, we do not assign the company to either of the groups. ${ }^{5}$

\subsection{Control firms}

To measure the effect of PE funding on firms' financial distress and bankruptcy risks, we analyze differences in the outcomes of the relevant variables of buyout firms and the outcomes of these variables for comparable non-buyout firms. A crucial feature in the construction of the counterfactual is the selection of a valid control group.

Randomization of treatment is infeasible in PE investments decisions for several reasons. The geographical and industry distribution of PE investments is not random. As to the industry, recent empirical studies suggests that PE funds are usually specialized investors who prefer investments in certain industries (e.g., Cressy et al., 2007). In addition, after taking the decision in which country and industry to invest, PE investors undertake an intensive screening and selection process in order to evaluate the investment strengths and risks, and to identify the "right" target firm (see Kaplan and Strömberg, 2004) with specific characteristics. These characteristics may shape financial distress and bankruptcy risks after the transaction. In addition, companies themselves may, at least to a certain extent, influence whether or not they obtain PE. To take into account these selection and self-selection effects, we run a matching procedure and identify "similar" non-buyout control firms to each buyout firm.

We employ propensity score matching, as suggested by Rosenbaum and Rubin (1983). The goal of this matching approach is to find "twin" firms which have similar characteristics as buyouts but were not acquired by a PE investor during the period under consideration. In order to identify a set of companies which do not differ significantly from the sample of buyouts in specific criteria, we first split the whole sample into 945 country-industry-year subsamples and run separate propensity score logit regressions in each subsample. By matching buyouts to controls in the same country and industry (1-digit NACE Rev. 2), year by year, we mitigate concerns that a non-random country/industry/time distribution of the buyouts could affect the results. We apply three-to-one nearest-neighbor matching with replacement. For each buyout firm we identify three control firms with similar size and age in the year prior to the transaction. Our final sample includes 5342 control firms. ${ }^{6}$

Table 2, Panel A delivers summary statistics on size, age, and our three distress risk measures for buyouts, control firms and all non-buyouts. Panel B suggests that the balancing property condition is fulfilled, i.e., the propensity scores for buyouts and nonbuyouts do not differ significantly. We provide a detailed description of the matching procedure in Appendix 2.

\section{Empirical results: financial distress}

Table 3 gives an overview of our three financial distress risk scores as well as their annual changes for buyouts and for control firms. All three scores indicate that buyout investors typically select companies with lower financial distress risks. The distress risk levels in the control group always exceed the distress risk levels in the buyout group in the year preceding the buyout year. For the O-score and the Z-score, but not for the Zmijewski-score, this is also true for the second year preceding the transaction. All three measures suggest that the distress risk increases significantly between the year preceding the buyout and three years after the buyout. On the contrary, for control companies, distress risk decreases as they grow older. Three years after the transaction, the buyout and control companies reach comparable distress risk levels.

In the next step we run multivariate panel regressions to investigate PE investors' impact in more detail. We include all years of all buyout and control companies in this analysis. We employ firm fixed effects to control for time-invariant and unobservable firm and industry characteristics. Moreover, we use year dummy variables to account for time-varying conditions such as the debt market situation. As errors are unlikely to be independent, we cluster them by company. We also control for industry concentration by using a Herfindahl-Hirschman-index. Dummy variable POST indicates the post-buyout period. For each dependent variable of interest, we estimate two specifications, with and without a lagged dependent variable. Our results, which we show in Table 4, indicate a statistically significant increase in financial distress after the buyout for all three measures.

In the following, we focus on the buyout sample only. We first investigate whether there are differences between syndicated and stand-alone buyouts. Descriptive statistics on the pre-buyout levels for both subgroups separately (Table 5, Panel A) suggest that syndicates are better able to handle financially distressed companies than stand-alone investors, who opt for companies with relatively low risks of financial distress. All three measures indicate that financial distress risks between syndicated and stand-alone transactions differ significantly in the year preceding the buyout. Two of the three distress risk measures (Zmijewski-score and O-score) suggest that this difference still prevails three years after the buyout.

Finally, we investigate how experienced and inexperienced PE investors differ. Table 5, Panel B indicates that both types of investors engage in companies with comparable financial distress risks. In the year preceding the buyout, the difference between both groups is insignificant for all three scores. In companies backed by experienced investors, financial distress risk significantly increases after the buyout. The difference in the financial distress risk change (during the period between the year preceding the buyout and three years after the buyout) between experienced and inexperienced investors is statistically significant only for the Zmijewski-score and the Z-score, but not the O-score.

Some scholars argue that the original financial distress risk models no longer fit with more recent data and estimate more upto-date coefficients. To check the robustness of our results, we employ these alternative coefficient values in additional analyses.

\footnotetext{
${ }^{5}$ Our results are robust towards excluding those companies for which the names of investors are not explicitly disclosed.

${ }^{6}$ The number of controls is less than three times the number of buyouts, as one control firm can be matched to more than one buyout firm (matching with replacement).
} 
Table 2

Summary statistics for buyouts, control firms and all non-buyouts.

\begin{tabular}{|c|c|c|c|c|c|}
\hline \multicolumn{6}{|l|}{ Panel A: Summary statistics } \\
\hline & Total Assets & Age & ZM-score & O-score & Z-score \\
\hline & (th. Euros) & (years) & & & \\
\hline (1) Buyouts (median) & 19,802 & 14 & -1.3771 & 0.5111 & 2.4903 \\
\hline (2) Matched control firms (median) & 20,139 & 16 & -1.2061 & 0.6191 & 2.2609 \\
\hline (3) Full sample non-buyouts (median) & 297 & 9 & -0.6326 & 0.9064 & 2.3873 \\
\hline Ranksum test (1) vs. (2) & 0.69 & 0.00 & 0.03 & 0.00 & 0.00 \\
\hline Ranksum test (1) vs. (3) & 0.00 & 0.00 & 0.00 & 0.00 & 0.10 \\
\hline No. observ. (1) & 1842 & 1842 & 1504 & 581 & 1376 \\
\hline No. observ. (2) & 5342 & 5342 & 4340 & 1809 & 3747 \\
\hline No. observ. (3) & $33,778,242$ & $32,288,668$ & $20,594,489$ & $12,895,619$ & $16,994,347$ \\
\hline \multicolumn{6}{|l|}{ Panel B: Balancing property } \\
\hline & \multicolumn{2}{|r|}{ median } & \multicolumn{2}{|r|}{ mean } & \\
\hline (1) Buyouts & \multicolumn{2}{|r|}{0.0007} & \multicolumn{2}{|r|}{0.0033} & \\
\hline (2) Control group & \multicolumn{2}{|r|}{0.0007} & \multicolumn{2}{|r|}{0.0030} & \\
\hline Test & \multicolumn{2}{|r|}{0.9282} & \multicolumn{2}{|r|}{0.3844} & \\
\hline
\end{tabular}

Panel A of this table reports medians of the variables total assets, age, and the indices measuring financial distress - Zmijewski-score, O-score and Z-score - for (1) the sample of firms that were involved in a buyout in 2000-2008 in the EU-15 compared to (2) the matched control group and to (3) the full sample of non-buyouts. The full sample of non-buyouts includes all firms not involved in a buyout which operate in country-industry-years where at least one buyout was executed. The data for the firms involved in buyouts and control firms correspond to the year before the transaction. The data for the full sample of non-buyout firms correspond to the whole time period from 2000 to 2008. Variable definitions are provided in Appendix 1 . The number of observations varies across items due to data availability. Panel B shows the propensity scores of the samples of buyouts and control firms as well as tests for the equality of means (t-test allowing for unequal variances) and the equality of distributions (Wilcoxon-Mann-Whitney ranksum test) between both groups.

We follow the suggestions by Begley et al. (1996) and Hillegeist et al. (2004) for the Z-score and the O-score. Moreover, we use coefficients calculated by Shumway (2001), who uses hazard-rate models, for the Z-score and the Zmijewski-score. In another robustness check, we investigate whether particular countries, industries or years drive our results. We remove one country or

Table 3

Median values and median changes from the pre-transaction period to the post-transaction period for buyout and control firms.

\begin{tabular}{|c|c|c|c|c|c|c|c|c|c|}
\hline & \multicolumn{6}{|c|}{ Values } & \multicolumn{3}{|c|}{ Changes } \\
\hline & \multicolumn{9}{|c|}{ ZM-score (higher values indicate larger distress) } \\
\hline Year (transaction year=0) & $t=-3$ & $\mathrm{t}=-2$ & $\mathrm{t}=-1$ & $\mathrm{t}=1$ & $\mathrm{t}=2$ & $\mathrm{t}=3$ & $-1 / 1$ & $-1 / 2$ & $-1 / 3$ \\
\hline Buyouts (median) & -1.2022 & -1.2493 & -1.3771 & -1.2053 & -1.2285 & -1.3508 & $13.9123^{* * *}$ & $13.6600^{* * *}$ & $23.5356^{* * *}$ \\
\hline Control firms (median) & -1.1867 & -1.1780 & -1.2061 & -1.3441 & -1.2637 & -1.3730 & $-3.7778^{* *}$ & $-3.2540^{* *}$ & $-6.2178^{*}$ \\
\hline Ranksum test & 0.5782 & 0.7548 & $0.0348^{* *}$ & $0.0788^{*}$ & 0.5337 & 0.3685 & $0.0000^{* * *}$ & $0.0000^{* * *}$ & $0.0000^{* * *}$ \\
\hline No. observ. (buyouts) & 1227 & 1387 & 1504 & 965 & 674 & 457 & 857 & 605 & 413 \\
\hline \multirow[t]{2}{*}{ No. observ. (control firms) } & 3295 & 3812 & 4340 & 3019 & 2104 & 1405 & 2837 & 1972 & 1306 \\
\hline & \multicolumn{9}{|c|}{ O-score (higher values indicate larger distress) } \\
\hline Year (transaction year=0) & $\mathrm{t}=-3$ & $\mathrm{t}=-2$ & $\mathrm{t}=-1$ & $\mathrm{t}=1$ & $\mathrm{t}=2$ & $t=3$ & $-1 / 1$ & $-1 / 2$ & $-1 / 3$ \\
\hline Buyouts (median) & 0.5794 & 0.5246 & 0.5111 & 0.5602 & 0.5687 & 0.6389 & $3.4612^{* * *}$ & 2.0423 & $8.6399^{* * *}$ \\
\hline Control firms (median) & 0.6174 & 0.6092 & 0.6191 & 0.6057 & 0.6220 & 0.5649 & $-0.4132^{* *}$ & -0.5850 & -0.6424 \\
\hline Ranksum test & 0.2580 & $0.0078^{* * *}$ & $0.0004^{* * *}$ & 0.6112 & 0.4683 & 0.1581 & $0.0001^{* * *}$ & 0.1301 & $0.0007^{* * *}$ \\
\hline No. observ. (buyouts) & 507 & 553 & 581 & 360 & 222 & 165 & 245 & 150 & 108 \\
\hline \multirow[t]{2}{*}{ No. observ. (control firms) } & 1380 & 1619 & 1809 & 1274 & 873 & 594 & 963 & 619 & 401 \\
\hline & \multicolumn{9}{|c|}{ Z-score (lower values indicate larger distress) } \\
\hline Year (transaction year=0) & $t=-3$ & $t=-2$ & $\mathrm{t}=-1$ & $\mathrm{t}=1$ & $\mathrm{t}=2$ & $\mathrm{t}=3$ & $-1 / 1$ & $-1 / 2$ & $-1 / 3$ \\
\hline Buyouts (median) & 2.3437 & 2.4575 & 2.4903 & 2.3715 & 2.3328 & 2.4435 & $-6.6952^{* * *}$ & $-11.9328^{* * *}$ & $-10.3538^{* *}$ \\
\hline Control firms (median) & 2.3508 & 2.2910 & 2.2609 & 2.3613 & 2.3249 & 2.2723 & $5.3638^{* * *}$ & $5.6296^{* * *}$ & $8.9846^{* * *}$ \\
\hline Ranksum test & 0.9298 & $0.0016^{* * *}$ & $0.0001^{* * *}$ & 0.6379 & 0.8293 & 0.1551 & $0.0000^{* * *}$ & $0.0000^{* * *}$ & $0.0001^{* * *}$ \\
\hline No. observ. (buyouts) & 1122 & 1278 & 1376 & 814 & 590 & 389 & 722 & 519 & 344 \\
\hline No. observ. (control firms) & 2909 & 3318 & 3747 & 2453 & 1734 & 1110 & 2295 & 1610 & 1015 \\
\hline
\end{tabular}

This table shows medians of the indices measuring financial distress - Zmijewski-score, O-score, and the Z-score - for the sample of firms involved in a buyout in 20002008 in the EU-15 and for the control firms. The variables are presented for a time horizon of three years prior to the transaction to three years after the transaction. The changes (in percentage points) are measured from the year prior to the buyout through the third year following each buyout (year - 1 to years 1,2 , and 3 ). We test for the equality of distributions (Wilcoxon-Mann-Whitney ranksum test) between the two groups of firms. Moreover, we test whether the changes are significantly different from zero (denoted by asterisks) by using a Wilcoxon signed-ranks test for medians. Variable definitions are provided in Appendix 1. The number of observations varies across items due to data availability. ${ }^{* * *},{ }^{* *},{ }^{*}$ denote significance at the $1 \%, 5 \%$ and $10 \%$ level, respectively. 
Table 4

Panel regressions for buyouts and control firms.

\begin{tabular}{|c|c|c|c|c|c|c|}
\hline & \multicolumn{2}{|l|}{ ZM-score } & \multicolumn{2}{|l|}{ O-score } & \multicolumn{2}{|l|}{ Z-score } \\
\hline & $(1)$ & $(2)$ & (3) & $(4)$ & (5) & (6) \\
\hline POST & $\begin{array}{l}0.2079^{* * *} \\
(0.052)\end{array}$ & $\begin{array}{l}0.1514^{* * *} \\
(0.039)\end{array}$ & $\begin{array}{l}0.0484^{* * * *} \\
(0.013)\end{array}$ & $\begin{array}{l}0.0550^{* * * *} \\
(0.013)\end{array}$ & $\begin{array}{l}-0.1271^{* * *} \\
(0.037)\end{array}$ & $\begin{array}{l}-0.0937^{* * * *} \\
(0.029)\end{array}$ \\
\hline Lag dep. var. & & $\begin{array}{l}0.4012^{* * *} \\
(0.015)\end{array}$ & & $\begin{array}{l}0.1871^{* * *} \\
(0.018)\end{array}$ & & $\begin{array}{l}0.3015^{* * *} \\
(0.017)\end{array}$ \\
\hline $\mathrm{HHI}$ & $\begin{array}{l}0.0467 \\
(0.089)\end{array}$ & $\begin{array}{l}-0.0571 \\
(0.118)\end{array}$ & $\begin{array}{l}-0.0488 \\
(0.046)\end{array}$ & $\begin{array}{l}-0.0215 \\
(0.052)\end{array}$ & $\begin{array}{l}0.2016^{* *} \\
(0.087)\end{array}$ & $\begin{array}{l}0.2763^{* * *} \\
(0.091)\end{array}$ \\
\hline Year fixed effects & Yes & Yes & Yes & Yes & Yes & Yes \\
\hline Firm fixed effects & Yes & Yes & Yes & Yes & Yes & Yes \\
\hline Constant & Yes & Yes & Yes & Yes & Yes & Yes \\
\hline F-value & 8.1764 & 71.9198 & 16.7207 & 22.3977 & 4.2998 & 30.2234 \\
\hline No. observ. & 43,348 & 35,549 & 17,135 & 12,508 & 38,960 & 31,552 \\
\hline
\end{tabular}

This table reports the coefficients (and standard errors in parentheses) from panel regressions with the indices measuring financial distress - Zmijewski-score, O-score and Z-score - as dependent variables. POST is a dummy variable with a value of 1 for buyouts in the years after a buyout transaction. HHI is the Herfindahl-Hirschman-Index measuring market concentration. All regressions include a constant, year and firm fixed effects. Dependent variables definitions are provided in Appendix 1. Standard errors are clustered by company. ${ }^{* * *},{ }^{* *},{ }^{*}$ denote significance at the $1 \%, 5 \%$ and $10 \%$ level, respectively.

one industry or one year at a time from the sample and analyze whether the results change. All in all, these robustness checks (not displayed, but available upon request) do not alter the main results of our previous analyses.

\section{Empirical results: bankruptcy}

The main potential caveat with our analyses in the previous section is that we have only investigated distress risks based on accounting figures, but not real distress. In other words, we have not checked whether companies end in bankruptcy more or less often after the buyout than comparable non-buyout companies and how bankruptcy rates differ with different characteristics of PE investments. We address this issue in this section. More specifically, we analyze how the probability of bankruptcy is related to the buyout event and to different buyout characteristics (syndicated transactions, stand-alone transactions, buyouts of experienced and of inexperienced PE investors). In addition, we examine whether bankruptcies are more common in companies which realized a buyout in years with favorable debt market conditions. To investigate the impact of debt market conditions on the behavior of buyout investors, we employ the high-yield spread (see Axelson et al., 2010), defined as the Europe high-yield rate for the corresponding year according to the Merrill Lynch High-Yield index minus Libor (both obtained from Datastream). For our analyses, we distinguish between buyouts in years with favorable vs. unfavorable conditions, which we measure as high-yield spreads below vs. above their sample period median. According to this definition, debt market conditions were favorable in the period 2004-2007.

Table 6 depicts the regression results. The dependent variable BANKRUPTCY is binary and takes a value of one if the firm goes bankrupt in the time period 2000-2010 and zero otherwise. We obtained information on a failure of our sample firms within this period from the Orbis database. In all regressions, we control for firm-specific characteristics (age, size) and for the general economic environment (business confidence indicator, domestic credit to private sector, real economic growth, severity of the bankruptcy law, and consumer price index) that may affect bankruptcy likelihood. We also add industry fixed effects.

Column (1) shows the results from a logit estimation with all buyout companies and our (matched) control companies. The central variable of interest is the dummy variable BUYOUT, which equals one for buyouts and zero otherwise. The marginal effect is insignificant, which suggests that the bankruptcy likelihood is not higher for buyout companies than for comparable non-buyout companies.

In column (2) we adopt an instrumental variable approach as proposed by Ackerberg and Botticini (2002). The starting point of this approach is the recognition that PE investments are not random, but are concentrated in certain countries and industries. The availability of suitable buyout targets in certain countries and industries affects the intensity of PE financing. Instead of using this recognition for the matching procedure, we employ it as the basis on which we generate our instruments. This approach has been applied in a context of bankruptcy analysis by Bhattacharya et al. (2011). Following Bhattacharya et al. (2011) and Du (2010), we construct local market variables by combining industries and countries into pairs. By interaction between 9 (1-digit NACE Rev. 2) industries and 15 countries, we obtain 135 local markets which we use as instruments. Bhattacharya et al. (2011) argue that such instruments are valid because local characteristics should not directly affect the bankruptcy of a single firm. Similar variables have been used as an instrument for venture capital financing by e.g., Bottazzi et al. (2008) or Du (2010). This estimation includes all buyouts and all non-buyout companies, resulting in more than 7 million observations. We only depict the results from the second stage regression. The coefficient on the buyout dummy is insignificant. Thus, we again conclude that bankruptcy likelihood is not affected by the buyout event.

Column (3) adds Zmijewski-score as an additional control variable to the first specification. Its marginal effect is highly statistically significant and positive, as expected, indicating that higher distress risks are associated with a higher likelihood of bankruptcy. Moreover, adding the Zmijewski-score does not affect the marginal effect of the buyout variable, which remains insignificant.

In Columns (4), (5), and (6) we investigate how different types of buyouts are related to bankruptcy likelihood. We first distinguish between buyouts in favorable and unfavorable debt market conditions. Our results in Column (4) suggest that even for companies that are subject to buyouts in years when cheap financing is available, bankruptcy risk does not exceed the risk of comparable non-buyout companies. Second, we differentiate between syndicated and stand-alone transactions. Column (5) 
Table 5

Median values and median changes from the pre-transaction period to the post-transaction period (syndicated vs. stand-alone transactions, transactions with experienced vs. inexperienced PE investors).

\begin{tabular}{|c|c|c|c|c|c|c|c|c|c|}
\hline $\begin{array}{l}\text { Panel A: Syndicated vs. } \\
\text { stand-alone transactions }\end{array}$ & \multicolumn{6}{|c|}{ Values } & \multicolumn{3}{|c|}{ Changes } \\
\hline & \multicolumn{9}{|c|}{ ZM-score (higher values indicate larger distress) } \\
\hline Year $($ transaction year $=0$ ) & $t=-3$ & $\mathrm{t}=-2$ & $\mathrm{t}=-1$ & $\mathrm{t}=1$ & $\mathrm{t}=2$ & $\mathrm{t}=3$ & $-1 / 1$ & $-1 / 2$ & $-1 / 3$ \\
\hline Syndicated (median) & -0.8336 & -1.0236 & -1.1786 & -1.0940 & -1.1004 & -0.5699 & 0.0820 & 0.0233 & $0.6751^{*}$ \\
\hline Stand-alone (median) & -1.3300 & -1.2760 & -1.4171 & -1.1873 & -1.2568 & -1.2773 & $0.1846^{* * *}$ & $0.2066^{* * *}$ & $0.3612^{* * *}$ \\
\hline Ranksum test & $0.0153^{* *}$ & 0.1531 & $0.0328^{* *}$ & 0.6705 & 0.8734 & $0.0794^{*}$ & 0.2124 & 0.4004 & 0.5672 \\
\hline No. observ. (syndicated) & 194 & 219 & 232 & 138 & 92 & 45 & 130 & 87 & 42 \\
\hline \multirow[t]{2}{*}{ No. observ. (stand-alone) } & 792 & 867 & 923 & 552 & 362 & 237 & 484 & 320 & 214 \\
\hline & \multicolumn{9}{|c|}{ O-score (higher values indicate larger distress) } \\
\hline Year (transaction year = 0) & $\mathrm{t}=-3$ & $t=-2$ & $\mathrm{t}=-1$ & $\mathrm{t}=1$ & $\mathrm{t}=2$ & $t=3$ & $-1 / 1$ & $-1 / 2$ & $-1 / 3$ \\
\hline Syndicated (median) & 0.6973 & 0.5938 & 0.6050 & 0.5794 & 0.6980 & 0.8785 & 0.0303 & -0.0172 & $0.1731^{* * *}$ \\
\hline Stand-alone (median) & 0.5684 & 0.5255 & 0.4889 & 0.5668 & 0.5687 & 0.6726 & $0.0524^{* * *}$ & $0.0652^{* *}$ & $0.1086^{* * *}$ \\
\hline Ranksum test & $0.0298^{* *}$ & 0.2940 & $0.0599^{*}$ & 0.7654 & 0.6691 & $0.0729^{*}$ & 0.4639 & 0.3611 & 0.7100 \\
\hline No. observ. (syndicated) & 86 & 90 & 92 & 54 & 28 & 18 & 44 & 23 & 13 \\
\hline \multirow[t]{2}{*}{ No. observ. (stand-alone) } & 319 & 358 & 358 & 208 & 115 & 78 & 136 & 7 & 49 \\
\hline & \multicolumn{9}{|c|}{ Z-score (lower values indicate larger distress) } \\
\hline Year (transaction year = 0) & $\mathrm{t}=-3$ & $t=-2$ & $\mathrm{t}=-1$ & $\mathrm{t}=1$ & $\mathrm{t}=2$ & $t=3$ & $-1 / 1$ & $-1 / 2$ & $-1 / 3$ \\
\hline Syndicated (median) & 2.2530 & 2.2287 & 2.2687 & 2.2221 & 1.8621 & 1.9405 & -0.0307 & -0.1161 & -0.1027 \\
\hline Stand-alone (median) & 2.3350 & 2.4857 & 2.5391 & 2.3542 & 2.4331 & 2.4834 & $-0.1036^{* * *}$ & $-0.1713^{* * *}$ & $-0.1591^{* *}$ \\
\hline Ranksum test & 0.4310 & 0.2338 & $0.0385^{* *}$ & 0.3688 & $0.0528^{*}$ & 0.3181 & 0.3286 & 0.4922 & 0.7276 \\
\hline No. observ. (syndicated) & 192 & 216 & 225 & 126 & 75 & 38 & 122 & 73 & 35 \\
\hline No. observ. (stand-alone) & 716 & 798 & 848 & 447 & 307 & 197 & 395 & 269 & 177 \\
\hline
\end{tabular}

\begin{tabular}{|c|c|c|c|c|c|c|c|c|c|}
\hline $\begin{array}{l}\text { Panel B: Experienced vs. } \\
\text { inexperienced investors }\end{array}$ & \multicolumn{6}{|c|}{ Values } & \multicolumn{3}{|c|}{ Changes } \\
\hline & \multicolumn{9}{|c|}{ ZM-score (higher values indicate larger distress) } \\
\hline Year (transaction year $=0$ ) & $t=-3$ & $\mathrm{t}=-2$ & $\mathrm{t}=-1$ & $\mathrm{t}=1$ & $\mathrm{t}=2$ & $\mathrm{t}=3$ & $-1 / 1$ & $-1 / 2$ & $-1 / 3$ \\
\hline Experienced (median) & -1.2135 & -1.2137 & -1.3335 & -1.0341 & -1.1025 & -0.8930 & $0.1620^{* * *}$ & $0.1336^{* * *}$ & $0.5549^{* *}$ \\
\hline Inexperienced (median) & -1.2293 & -1.3410 & -1.5088 & -1.3948 & -1.4967 & -1.6550 & $0.1690^{* *}$ & $0.1786^{*}$ & 0.1995 \\
\hline Ranksum test & 0.2346 & 0.3744 & 0.1383 & $0.0474^{* *}$ & $0.0470^{* *}$ & $0.0004^{* * *}$ & 0.6038 & 0.4653 & $0.0299^{* *}$ \\
\hline No. observ. (experienced) & 575 & 629 & 665 & 412 & 275 & 167 & 366 & 248 & 150 \\
\hline No. observ. (inexperienced) & 550 & 601 & 644 & 382 & 251 & 170 & 341 & 226 & 157 \\
\hline \multicolumn{10}{|c|}{ O-score (higher values indicate larger distress) } \\
\hline Year (transaction year $=0$ ) & $\mathrm{t}=-3$ & $\mathrm{t}=-2$ & $\mathrm{t}=-1$ & $\mathrm{t}=1$ & $\mathrm{t}=2$ & $\mathrm{t}=3$ & $-1 / 1$ & $-1 / 2$ & $-1 / 3$ \\
\hline Experienced (median) & 0.5639 & 0.4830 & 0.4889 & 0.6063 & 0.6045 & 0.6813 & $0.0524^{* *}$ & -0.0000 & $0.1179^{* * *}$ \\
\hline Inexperienced (median) & 0.5950 & 0.5952 & 0.5113 & 0.5533 & 0.5409 & 0.6169 & $0.0418^{* *}$ & $0.0759^{*}$ & $0.0681^{*}$ \\
\hline Ranksum test & 0.8265 & 0.1636 & 0.2277 & 0.7016 & 0.6851 & 0.5595 & 0.5994 & 0.6878 & 0.1236 \\
\hline No. observ. (experienced) & 229 & 251 & 242 & 151 & 88 & 57 & 106 & 61 & 35 \\
\hline No. observ. (inexperienced) & 245 & 259 & 279 & 154 & 82 & 60 & 109 & 60 & 44 \\
\hline & \multicolumn{9}{|c|}{ Z-score (lower values indicate larger distress) } \\
\hline Year (transaction year $=0$ ) & $\mathrm{t}=-3$ & $\mathrm{t}=-2$ & $\mathrm{t}=-1$ & $\mathrm{t}=1$ & $\mathrm{t}=2$ & $\mathrm{t}=3$ & $-1 / 1$ & $-1 / 2$ & $-1 / 3$ \\
\hline Experienced (median) & 2.3291 & 2.4684 & 2.4805 & 2.2581 & 2.1896 & 2.1794 & $-0.0753^{* *}$ & $-0.1447^{* * *}$ & $-0.1294^{* *}$ \\
\hline Inexperienced (median) & 2.3982 & 2.5038 & 2.5377 & 2.5548 & 2.5419 & 2.6604 & $-0.0842^{*}$ & $-0.1070^{*}$ & -0.1193 \\
\hline Ranksum test & 0.3476 & 0.4766 & 0.3175 & $0.0131^{* *}$ & $0.0060^{* * *}$ & $0.0266^{* *}$ & 0.7367 & 0.4082 & $0.0900^{*}$ \\
\hline No. observ. (experienced) & 524 & 585 & 620 & 339 & 234 & 139 & 312 & 214 & 124 \\
\hline No. observ. (inexperienced) & 507 & 553 & 586 & 322 & 215 & 141 & 283 & 191 & 128 \\
\hline
\end{tabular}

This table shows medians of the indices measuring financial distress - Zmijewski-score, O-score, and the Z-score - for the samples of syndicated and stand-alone transactions (Panel A) as well as for the samples of transactions with experienced and inexperienced PE investors (Panel B). The variables are presented for a time horizon of three years prior to the transaction to three years after the transaction. The changes (in percentage points) are measured from the year prior to each buyout through the third year following each buyout (year -1 to years 1,2 , and 3 ). We test for the equality of distributions (Wilcoxon-Mann-Whitney rank-sum test) between the two groups of transactions. Moreover, we test whether the changes are significantly different from zero (denoted by asterisks) by using a Wilcoxon signed-ranks test for medians. Variable definitions are provided in Appendix A. The number of observations varies across items due to data availability. ${ }^{* * *}{ }^{* *},{ }^{*}$ denote significance at the $1 \%, 5 \%$ and $10 \%$ level, respectively.

indicates that neither of the types affects bankruptcy likelihood. Finally, we distinguish between transactions by experienced and inexperienced PE investors. The results in Column (6) indicate that experienced PE investors decrease the likelihood of bankruptcy relative to non-buyout control companies. 
Table 6

Probability of bankruptcy.

\begin{tabular}{|c|c|c|c|c|c|c|c|c|c|}
\hline & $\begin{array}{l}\text { All buyouts } \\
\text { and controls }\end{array}$ & $\begin{array}{l}\text { All buyouts and } \\
\text { all non-buyouts }\end{array}$ & $\begin{array}{l}\text { All buyouts } \\
\text { and controls }\end{array}$ & $\begin{array}{l}\text { All buyouts } \\
\text { and controls }\end{array}$ & $\begin{array}{l}\text { All buyouts } \\
\text { and controls }\end{array}$ & $\begin{array}{l}\text { All buyouts } \\
\text { and controls }\end{array}$ & $\begin{array}{c}\text { Only } \\
\text { buyouts }\end{array}$ & $\begin{array}{c}\text { Only } \\
\text { buyouts }\end{array}$ & $\begin{array}{c}\text { Only } \\
\text { buyouts }\end{array}$ \\
\hline & Logit & IV & Logit & Logit & Logit & Logit & Logit & Logit & Logit \\
\hline & $(1)$ & $(2)$ & (3) & (4) & (5) & (6) & (7) & (8) & (9) \\
\hline \multicolumn{10}{|c|}{ Buyout and buyout characteristics } \\
\hline Buyout & $\begin{array}{c}-0.0002 \\
(0.002)\end{array}$ & $\begin{array}{l}-2.6990 \\
(3.104)\end{array}$ & $\begin{array}{l}0.0005 \\
(0.002)\end{array}$ & & & & & & \\
\hline Favorable & & & & $\begin{array}{c}-0.0013 \\
(0.002)\end{array}$ & & & $\begin{array}{c}-0.0082 \\
(0.005)\end{array}$ & & \\
\hline Unfavorable & & & & $\begin{array}{l}0.0075 \\
(0.005)\end{array}$ & & & & & \\
\hline Syndicated & & & & & $\begin{array}{c}-0.0022 \\
(0.002)\end{array}$ & & & $\begin{array}{c}-0.0024 \\
(0.003)\end{array}$ & \\
\hline Stand-alone & & & & & $\begin{array}{l}0.0002 \\
(0.001)\end{array}$ & & & & \\
\hline Experienced & & & & & & $\begin{array}{c}-0.0043^{* * *} \\
(0.002)\end{array}$ & & & $\begin{array}{c}-0.0069^{*} \\
(0.004)\end{array}$ \\
\hline Inexperienced & & & & & & $\begin{array}{l}0.0023 \\
(0.002)\end{array}$ & & & \\
\hline \multicolumn{10}{|l|}{ Firm characteristics } \\
\hline Age & $\begin{array}{c}-0.0003^{* * *} \\
(0.001)\end{array}$ & $\begin{array}{c}0.0062^{* * *} \\
(0.001)\end{array}$ & $\begin{array}{c}-0.0018 \\
(0.001)\end{array}$ & $\begin{array}{c}-0.0037^{* * *} \\
(0.001)\end{array}$ & $\begin{array}{c}-0.0031^{* * *} \\
(0.001)\end{array}$ & $\begin{array}{c}-0.0035^{* * *} \\
(0.001)\end{array}$ & $\begin{array}{c}-0.0039^{*} \\
(0.002)\end{array}$ & $\begin{array}{c}-0.0021 \\
(0.002)\end{array}$ & $\begin{array}{c}-0.0028 \\
(0.002)\end{array}$ \\
\hline Size & $\begin{array}{c}-0.0014^{* * * *} \\
(0.000)\end{array}$ & $\begin{array}{l}0.0004 \\
(0.001)\end{array}$ & $\begin{array}{c}-0.0015^{* * *} \\
(0.000)\end{array}$ & $\begin{array}{c}-0.0014^{* * *} \\
(0.000)\end{array}$ & $\begin{array}{c}-0.0011^{* * * *} \\
(0.000)\end{array}$ & $\begin{array}{c}-0.0012^{* * * *} \\
(0.000)\end{array}$ & $\begin{array}{c}-0.0011^{*} \\
(0.001)\end{array}$ & $\begin{array}{c}-0.0009 \\
(0.001)\end{array}$ & $\begin{array}{c}-0.0011^{*} \\
(0.001)\end{array}$ \\
\hline ZM-score & & & $\begin{array}{l}0.0015^{* * *} \\
(0.000)\end{array}$ & & & & & & \\
\hline \multicolumn{10}{|l|}{ Economic environment } \\
\hline Confidence & $\begin{array}{c}-0.0173^{* * *} \\
(0.003)\end{array}$ & $\begin{array}{c}-0.0240^{* * * *} \\
(0.002)\end{array}$ & $\begin{array}{c}-0.0149^{* * *} \\
(0.003)\end{array}$ & $\begin{array}{c}-0.0172^{* * *} \\
(0.003)\end{array}$ & $\begin{array}{c}-0.0155^{* * *} \\
(0.003)\end{array}$ & $\begin{array}{c}-0.0148^{* * *} \\
(0.002)\end{array}$ & $\begin{array}{c}-0.0169^{* * *} \\
(0.005)\end{array}$ & $\begin{array}{c}-0.0171^{* * * *} \\
(0.005)\end{array}$ & $\begin{array}{c}-0.0131^{* * *} \\
(0.005)\end{array}$ \\
\hline Credit & $\begin{array}{c}-0.0000^{* * * *} \\
(0.000)\end{array}$ & $\begin{array}{c}-0.0000^{* * *} \\
(0.000)\end{array}$ & $\begin{array}{c}-0.0000^{* * *} \\
(0.000)\end{array}$ & $\begin{array}{c}-0.0000^{* * *} \\
(0.000)\end{array}$ & $\begin{array}{c}-0.0000^{* * *} \\
(0.000)\end{array}$ & $\begin{array}{c}-0.0000^{\text {**** }} \\
(0.000)\end{array}$ & $\begin{array}{c}-0.0000^{* * *} \\
(0.000)\end{array}$ & $\begin{array}{c}-0.0000^{* * * *} \\
(0.000)\end{array}$ & $\begin{array}{c}-0.0000^{* * * *} \\
(0.000)\end{array}$ \\
\hline Growth & $\begin{array}{c}-0.0098^{* * *} \\
(0.002)\end{array}$ & $\begin{array}{c}-0.0313^{* * *} \\
(0.001)\end{array}$ & $\begin{array}{c}-0.0089^{* * *} \\
(0.002)\end{array}$ & $\begin{array}{c}-0.0095^{* * *} \\
(0.002)\end{array}$ & $\begin{array}{c}-0.0078^{* * *} \\
(0.002)\end{array}$ & $\begin{array}{c}-0.0076^{* * *} \\
(0.002)\end{array}$ & $\begin{array}{c}-0.0087^{* * *} \\
(0.003)\end{array}$ & $\begin{array}{c}-0.0074^{* * *} \\
(0.003)\end{array}$ & $\begin{array}{c}-0.0060^{* * *} \\
(0.002)\end{array}$ \\
\hline Bankruptcy law & $\begin{array}{c}-0.0001 \\
(0.000)\end{array}$ & $\begin{array}{c}0.0007^{* * *} \\
(0.000)\end{array}$ & $\begin{array}{c}-0.0001 \\
(0.000)\end{array}$ & $\begin{array}{c}-0.0001 \\
(0.000)\end{array}$ & $\begin{array}{c}-0.0000 \\
(0.000)\end{array}$ & $\begin{array}{c}-0.0000 \\
(0.000)\end{array}$ & $\begin{array}{c}-0.0002 \\
(0.000)\end{array}$ & $\begin{array}{c}-0.0001 \\
(0.000)\end{array}$ & $\begin{array}{c}-0.0001 \\
(0.000)\end{array}$ \\
\hline CPI & $\begin{array}{c}0.0258^{* * * *} \\
(0.003)\end{array}$ & $\begin{array}{c}0.0627^{* * *} \\
(0.005)\end{array}$ & $\begin{array}{c}0.0196^{* * * *} \\
(0.003)\end{array}$ & $\begin{array}{c}0.0253^{* * *} \\
(0.003)\end{array}$ & $\begin{array}{c}0.0217^{* * * *} \\
(0.003)\end{array}$ & $\begin{array}{c}0.0213^{* * *} \\
(0.003)\end{array}$ & $\begin{array}{c}0.0218^{* * * *} \\
(0.006)\end{array}$ & $\begin{array}{c}0.0200^{* * *} \\
(0.006)\end{array}$ & $\begin{array}{c}0.0157^{* * * *} \\
(0.005)\end{array}$ \\
\hline Industry fixed effects & Yes & Yes & Yes & Yes & Yes & Yes & Yes & Yes & Yes \\
\hline Constant & Yes & Yes & Yes & Yes & Yes & Yes & Yes & Yes & Yes \\
\hline Chi2/F & 240.14 & 45.00 & 277.74 & 242.63 & 199.23 & 222.97 & 68.64 & 72.44 & 104.46 \\
\hline No. observ. & 7184 & $7,216,964$ & 6174 & 7184 & 5718 & 6307 & 1842 & 1463 & 1613 \\
\hline
\end{tabular}

This table presents the marginal effects from cross-sectional logit estimations in Models (1) and (3) through (9) and from IV regressions in Model (2) with the dependent variable Bankruptcy, which takes a value of one if the firm goes bankrupt in the time period of 2000-2010 and a value of zero otherwise. Variable definitions are provided in Appendix 1. All regressions include a constant and industry fixed effects. The standard errors are clustered by country and industry. ${ }^{* * *}, * *, *$ denote significance at the $1 \%, 5 \%$ and $10 \%$ level, respectively.

Columns (7), (8), and (9) focus on the buyout sample only. We investigate the differences between buyouts in favorable vs. unfavorable debt market conditions in Column (7), between syndicated vs. stand-alone transactions in Column (8), and, finally, between buyouts of experienced vs. inexperienced PE investors in Column (9). The only difference we find exists between experienced and inexperienced PE investors. Experienced investors seem to decrease bankruptcy likelihood (compared to inexperienced investors). Obviously, experienced investors, who on the one hand increase distress risk in their portfolio companies more than inexperienced investors, are, on the other hand, better able to manage these risks.

These results are broadly confirmed by the following robustness checks: We employ other distress risk measures (O-score, Z-score as well as their alternative specifications developed by Begley et al. (1996), Hillegeist et al. (2004), and Shumway (2001)) in our third specification. Moreover, we estimate all regressions with these distress risk measures (including them one by one). In addition, we check whether particular countries, industries or years drive our results.

\section{Conclusion}

Our paper lends support to the hypothesis that private equity investors in Europe selected companies with lower financial distress risks (compared to non-buyouts) as buyout targets during the period 2000-2008. After the buyout, distress risk increased, but did not exceed that of comparable non-buyout companies. We do not find any support for the conjecture that private equity investors lead their companies into excessive financial distress ending in bankruptcy. Even those companies subject to buyouts in 
years when cheap debt financing was available did not suffer from higher bankruptcy rates than other buyouts and comparable non-buyout companies. In fact, when buyouts were backed by experienced private equity investors, their bankruptcy rates were even lower than those of comparable non-buyout companies. Companies backed by experienced investors also had lower bankruptcy rates than companies that were financed by inexperienced private equity investors, although the distress risk levels of the former were significantly higher after the buyout event. In addition, syndicates seem to be better able to handle financially distressed companies than stand-alone investors.

As our paper covers a dynamic and highly topical issue of private equity investors' impact, it contributes not only to academic research, but also to the recent policy discussion on regulation. Policy makers fear that private equity investors may have adverse effects on the financial system as a whole and induce contagion effects when large buyout credits fail. In response to these fears and to the global financial crisis, governments around the world are rethinking their approach to the regulation of financial institutions and financial markets, private equity investors being one of the central issues. The U.S. adopted new rules on hedge funds and private equity in July 2010 as part of the Dodd-Frank Act, and in Europe the AIFM directive on the regulation and supervision of managers of alternative investment funds was adopted in November 2010. These processes pose many questions concerning the role of private equity funds during the financial crisis, which may possibly be answered only after some time has passed. Our paper cannot ultimately answer the question of whether private equity investors are "visionaries" or "locusts". Nevertheless, it attempts to provide some insights into how private equity investors, who have become an influential and important part of European economies in recent years, affect their portfolio companies in these countries, in particular in terms of distress and bankruptcy risk.

\section{Appendix 1. Variable description and sources}

\begin{tabular}{|c|c|}
\hline $\begin{array}{l}\text { Dependent } \\
\text { variables }\end{array}$ & Description \\
\hline ZM-, O-, Z-score & Measures of financial distress. Formulas for the calculation of the measures are presented in Section 3. Source: Amadeus \\
\hline Bankruptcy & Binary variable that takes a value of one if the firm goes bankrupt within the time period 2000-2010 and zero otherwise. Source: Orbis \\
\hline $\begin{array}{l}\text { Independent } \\
\text { variables }\end{array}$ & Description \\
\hline \multicolumn{2}{|c|}{ Buyout and buyout characteristics } \\
\hline Buyout & Dummy variable that takes a value of one for buyout firms within the time period 2000-2008 and zero for non-buyout firms. Source: Zephyr \\
\hline Post & $\begin{array}{l}\text { Dummy variable that takes a value of one for buyout firms in the years after a buyout transaction and zero for the years prior to the } \\
\text { transaction and for control firms. Source: Zephyr }\end{array}$ \\
\hline Favorable & $\begin{array}{l}\text { Dummy variable that takes a value of one for buyouts that occur in years with favorable debt market conditions and zero for buyouts that } \\
\text { occur in years with unfavorable debt market conditions and for control firms. Favorable (resp. unfavorable) market conditions are when } \\
\text { the high-yield spread is below (resp. above) its sample period median. The high-yield spread is the Europe Merrill Lynch High-Yield index } \\
\text { minus Libor. Source: Datastream, Zephyr }\end{array}$ \\
\hline Unfavorable & $\begin{array}{l}\text { Dummy variable that takes a value of one for buyouts that occur in years with unfavorable debt market conditions and zero for buyouts } \\
\text { that occur in years with favorable debt market conditions and for control firms. Favorable (resp. unfavorable) market conditions are when } \\
\text { the high-yield spread is below (resp. above) its sample period median. The high-yield spread is the Europe Merrill Lynch High-Yield index } \\
\text { minus Libor. Source: Datastream, Zephyr }\end{array}$ \\
\hline Syndicated & $\begin{array}{l}\text { Dummy variable equal to one for syndicated buyouts and zero for stand-alone buyouts and for control firms. A transaction is classified as } \\
\text { syndicated if the number of private equity funds is disclosed and is larger than one. Source: Zephyr }\end{array}$ \\
\hline Stand-alone & $\begin{array}{l}\text { Dummy variable equal to one for stand-alone buyouts and zero for syndicated buyouts and for control firms. A transaction is classified as } \\
\text { stand-alone if the number of private equity funds is disclosed and equals one. Source: Zephyr }\end{array}$ \\
\hline Experienced & $\begin{array}{l}\text { Dummy variable equal to one for buyouts in which the average PE investor experience exceeds one, zero otherwise (buyouts with } \\
\text { inexperienced investors and control firms). We proxy the experience of each PE investor in a particular transaction by the number of all } \\
\text { transactions this PE investor carried out prior to this transaction. If the "name" of the acquirer is management byuout team, private } \\
\text { individuals, or similar (i.e., there is information in this field, but the name is not explicitly disclosed), we set the dummy equal to zero. If } \\
\text { the name is missing completely, the dummy variable is set to missing. Source: Zephyr }\end{array}$ \\
\hline Inexperienced & $\begin{array}{l}\text { Dummy variable equal to one for buyouts with inexperienced investors (average PE experience in this transaction is one or below) and } \\
\text { zero for buyouts with experienced investors and for control firms. We proxy the experience of each PE investor in a particular transaction } \\
\text { by the number of all transactions this PE investor carried out prior to this transaction. If the "name" of the acquirer is management byuout } \\
\text { team, private individuals, or similar (i.e., there is information in this field, but the name is not explicitly disclosed), we set the dummy } \\
\text { equal to one. If the name is missing completely, the dummy variable is set to missing. Source: Zephyr }\end{array}$ \\
\hline \multicolumn{2}{|c|}{ Firm characteristics } \\
\hline Age & Natural logarithm of one plus the age of the firm (in years). Source: Amadeus \\
\hline Size & Natural logarithm of one plus total assets. Source: Amadeus \\
\hline \multicolumn{2}{|r|}{ Economic environment } \\
\hline HHI & Herfindahl-Hirschman-index. Sum of the squares of each company market share in an industry, country, and year. Source: Amadeus \\
\hline Confidence & Business confidence indicator. Source: OECD \\
\hline Credit & Domestic credit to private sector as percentage of GDP. Source: Worldbank \\
\hline Growth & Real economic growth. Source: World Competitiveness Yearbook \\
\hline Bankruptcy law & Time to discharge in bankruptcy. Source: Armour and Cumming (2008) \\
\hline CPI & Consumer price index, change to previous year (in\%). Source: Datastream \\
\hline
\end{tabular}




\section{Appendix 2. Matching}

In each industry and country, buyout firms and non-buyout firms constitute a separate estimation sample for matching regressions. In order to obtain a sufficient number of potential matching companies in each industry, we use the 1-digit NACE Rev. 2 industry classification. Within each of these industry-country groups, year by year, we apply logit models with the dependent variable buyout to calculate the firms' propensity scores. We end-up with 945 different models. As independent variables we use the logarithms of total assets and age in the year prior to the transaction for the buyout firms and one-year lagged values of these variables for the non-buyout firms.

The 945 models provide propensity scores which express the firms' conditional probability to be acquired by a PE investor. We identify the matching partners for each buyout firm by minimizing the propensity score distance between buyout and nonbuyout firms (nearest-neighbors criterion). Three main methodological issues arise in matching (see Dehejia and Wahba, 2002): whether to match with or without replacement, which matching method to apply and, finally, how many control firms to match to each buyout firm. We choose to match with replacement. Thus, each buyout firm can be matched to the nearest non-buyout firm, even if a control firm is matched more than once. Matching with replacement produces less-biased matches. We apply the nearest-neighbor method. Finally, we select the three best control firms (propensity scores are closest to that of the buyout firm).

In order to meaningfully employ matching, it is necessary to condition on the support common to both buyout and nonbuyout companies (Heckman et al., 1998). Implementing the common support condition ensures that any combination of characteristics observed in the buyout group can also be observed in the control group. As a method we employ the minima and maxima comparison and delete all observations whose propensity score is smaller than the minimum and or larger than the maximum in the opposite group (see Caliendo and Kopeinig, 2008). In addition, we check whether the matching procedure is able to balance the distribution of the relevant variables in both the control and buyout group ("balancing property").

The decision on how many control firms to match with each buyout firm results in a trade-off between bias and precision of the estimates. By using more comparison firms, the precision of the estimates increases, but the bias increases as well. As robustness checks, we use one-to-one matching and caliper matching within a maximum distance of $25 \%$ propensity score standard deviation of controls to buyouts (see Cochran and Rubin, 1973). The former considers the first nearest neighbor, whereas the latter considers all control firms for which the propensity score difference is within a predefined radius. Caliper matching is more efficient as long as the distributions of the propensity scores of buyouts and non-buyouts overlap. The approach identifies as many control firms as are available within the calipers, which could be a large (small) number when many (few) good matches are available. Following Rosenbaum and Rubin's (1985) suggestion, we use a quarter standard deviation of the propensity scores as caliper width. Our main results are robust towards these alternative matching approaches.

\section{References}

Abdesselam, R., Cieply, S., Nadant, A.-L., 2008. Are corporate governance systems typologies relevant? Evidence from European transfers of ownership rights. Corp. Ownership Control 5 (2), 87-89.

Ackerberg, D.A., Botticini, M., 2002. Endogenous matching and the empirical determinants of contract form. J. Pol. Econ. 110 (3), 564-591.

Altman, E.I., 1968. Financial ratios, discriminant analysis and the prediction of corporate bankruptcy. J. Finance 23, 589-609.

Altman, E.I., 2002. Corporate distress prediction models in a turbulent economic and Basel II environment. NYU Working Paper No. S-CDM-02-11.

Armour, J., Cumming, D., 2008. Bankruptcy law and entrepreneurship. Am. Law Econ. Rev. 10 (2), 303-350.

Axelson, U., Jenkinson, T., Strömberg, P., Weisbach, M.S., 2010. Borrow cheap, buy high? The determinants of leverage and pricing in buyouts. Ohio State University, Charles A. Dice Center for Research in Financial Economics (Working Paper Series 2010-9).

Begley, J., Ming, J., Watts, S., 1996. Bankruptcy classification errors in the 1980s: An empirical analysis of Altman's and Ohlson's models. Rev. Account. Stud. 1, 267-284.

Beuselinck, C., Deloof, M., Manigart, S., 2009. Private equity involvement and earnings quality. J. Bus. Finance Account. 36 (5-6), $587-615$.

Bhattacharya, U., Borisov, A., Yu, X., 2011. Do financial intermediaries during IPOs affect long-term firm mortality rates?. (Working Paper)

Bloom, N., Sadun, R., Van Reenen, J., 2010. Do private equity owned firms have better management practices? CEP Occasional Paper 24.

Bottazzi, L., da Rin, M., Hellmann, T., 2008. Who are the active investors? Evidence from venture capital. J. Financ. Econ. 89 (3), $488-512$.

Brander, J.A., Amit, R., Antweiler, W., 2002. Venture-capital syndication: improved venture selection vs. the value-added hypothesis. J. Econ. Manag. Strategy 11 (3), 422-451.

Brav, A., Brav, O., Jiang, W., 2009. The choice of going public and going private: evidence from UK. Working paper, Columbia University.

Caliendo, M., Kopeinig, S., 2008. Some practical guidance for the implementation of propensity score matching. J. Econ. Surv. 22 (1), $31-72$.

Casamatta, C., Haritchabalet, C., 2007. Experience, screening and syndication in venture capital investments. J. Financ. Intermed. 16 (3), $368-398$.

Citron, D., Wright, M., 2008. Bankruptcy costs, leverage and multiple secured creditors: the case of management buyouts. Account. Bus. Res. $38,71-89$.

Cochran, W.G., Rubin, D.B., 1973. Controlling bias in observational studies: a review. Sankhya: Indian J. Stat., Ser. A $417-446$.

Cressy, R., Munari, F., Malipiero, A., 2007. Playing to their strengths? Evidence that specialization in the private equity industry confers competitive advantage. J. Corp. Finance 13 (4), 647-669.

Cumming, D., Walz, U., 2010. Private equity returns and disclosure around the world. J. Int. Bus. Stud. 41 (4), 727-754.

Davis, S.J., Haltiwanger, J., Jarmin, R., Lerner, J., Miranda, J., 2008. Private equity and employment. The Global Economic Impact of Private Equity Report 2008: World Economic Forum.

Davis, S.J., Haltiwanger, J., Jarmin, R., Lerner, J., Miranda, J., 2009. Private equity, jobs and productivity. The Global Economic Impact of Private Equity Report 2009: World Economic Forum.

Dehejia, R.H., Wahba, S., 2002. Propensity score-matching methods for nonexperimental causal studies. Rev. Econ. Stat. 84 (1), 151-161.

Demiroglu, C., James, C.M., 2010. The role of private equity group reputation in LBO financing. J. Financ. Econ. 96 (2), $306-330$.

Du, Q., 2010. Birds of feather or celebrating differences? The formation and impact of venture capital syndication. Working Paper. Shanghai Advanced Institute of Finance.

Filatotchev, I., Wright, M., Arberk, M., 2006. Venture capitalists, syndication and governance in initial public offerings. Small Bus. Econ. 26, 337-350.

Goossens, L., Manigart, S., Meuleman, M., 2008. The change in ownership after a buyout: impact on performance. J. Priv. Equity 12 (1), $31-41$.

Griffin, J., Lemmon, M., 2002. Book-to-market equity, distress risk and stock returns. J. Finance 57, 2317-2336. 
Guo, S., Hotchkiss, E.S., Song, W., 2011. Do buyouts (still) create value? J. Finance 66, 479-517.

Harris, R., Siegel, D.S., Wright, M., 2005. Assessing the impact of management buyouts on economic efficiency: plant-level evidence from the United Kingdom. Rev. Econ. Stat. 87 (1), 148-153.

Heckman, J.J., Ichimura, H., Todd, P., 1998. Matching as an econometric evaluation estimator. Rev. Econ. Stud. 65 (2), 261-294.

Hillegeist, S.A., Keating, E.K., Cram, D.P., Lundstedt, K.G., 2004. Assessing the probability of bankruptcy. Rev. Account. Stud. 9, 5-34.

Ivashina, V., Kovner, A., 2011. The private equity advantage: leveraged buyout firms and relationship banking. Rev. Financial Stud. 24, 2462-2498.

Jensen, M.C., 1986. Agency costs of free cash flow, corporate finance, and takeovers. Am. Econ. Rev. 76 (2), 323-329.

Jensen, M.C., 1989. Eclipse of the public corporation. Harv. Bus. Rev. 67 (5), 61-74.

Kaplan, S.N., 1989. The effects of management buyouts on operating performance and value. J. Financ. Econ. 24 (2), 217-254.

Kaplan, S.N., Stein, J.C., 1993. The evolution of buyout pricing and financial structure in the 1980s. Q. J. Econ. 108 (2), 313-357.

Kaplan, S.N., Strömberg, P., 2004. Characteristics, contracts, and actions: evidence from venture capitalist analyses. J. Finance 59 (5), $2177-2210$.

Kaplan, S.N., Strömberg, P., 2009. Leveraged buyouts and private equity. J. Econ. Perspect. 23 (1), 121-146.

Lerner, J., 1994. The syndication of venture capital investments. J. Financ. Manag. Assoc. 23 (3), 16-27.

Lerner, J., Sorensen, M., Strömberg, P., 2011. Private equity and long-run investment: the case of innovation. J. Finance 66 (2), 445-477.

Lichtenberg, F.R., Siegel, D., 1990. The effects of leveraged buyouts on productivity and related aspects of firm behavior. J. Financ. Econ. 27 (1), $165-194$.

Nahata, R., 2008. Venture capital reputation and investment performance. J. Financ. Econ. 90 (2), 127-151.

Ohlson, J., 1980. Financial ratios and the probabilistic prediction of bankruptcy. J. Account. Res. 19, 109-131.

Phalippou, L., Zollo, M., 2005. What drives private equity fund performance? Working Paper. Financial Institutions Center at The Wharton School.

Popov, A., Roosenboom, P., 2009. Does private equity investment spur innovation? Evidence from Europe (ECB Working paper No. 1063).

Prijcker, S., Manigart, S., Wright, M., Maeseneire, W.D., 2009. The influence of international human capital and international network relationships on the crossborder investment behaviour of private equity firms. Working Paper. Ghent University.

Rosenbaum, P.R., Rubin, D.B., 1983. The central role of the propensity score in observational studies for causal effects. Biometrika 70, 41-55.

Rosenbaum, P.R., Rubin, D.B., 1985. The bias due to incomplete matching. Biometrics 41, 103-116.

Schertler, A., Tykvová, T., 2011. Venture capital and internationalization. Int. Bus. Rev. 20, 423-439.

Shumway, T., 2001. Forecasting bankruptcy more accurately: a simple hazard model. J. Bus. 74 (1), 101-124.

Smith, A.J., 1990. Corporate ownership structure and performance: the case of management buyouts. J. Financ. Econ. 27 (1), 143-164.

Sorensen, M., 2007. How smart is smart money?A two-sided matching model of venture capital. J. Finance 62 (6), 2725-2762.

Tian, X., 2011. The role of venture capital syndication in value creation for entrepreneurial firms. Rev. Finance 15 (3), 1-39.

Wright, M., Lockett, A., 2003. The structure and management of alliances: syndication in the venture capital industry. J. Manag. Stud. 40 (8), $2073-2102$.

Zmijewski, M.E., 1984. Methodological issues related to the estimation of financial distress prediction models. J. Account. Res. 22, 59-82. 